\section{A Case Study of How Visually Impaired Learners Acquire Language}

\author{
1 Thi Minh Phuong Tran \\ 2 Phuong Dzung Pho
}

12 University of Social Sciences and Humanities, Vietnam National University - Ho Chi Minh City, Vietnam

\begin{abstract}
The field of second language acquisition has grown enormously in the past decades. Many studies have been done on how learners acquire English as a second language; however, research on how visually impaired learners acquire English as a second or foreign language has been relatively scarce. It is even more difficult to find such studies in Vietnam. Based mainly on in-depth interviews with two visually impaired Vietnamese adults who have been successful in acquiring English, the present study seeks to answer two main questions: (1) How Vietnamese visually impaired learners acquire English as a foreign language; (2) What difficulties they have in learning English, and how they overcome their difficulties. The findings of the present study can contribute to the theory of second language acquisition and language teaching. The study can also provide strategies of practicing and learning language not only for visually impaired learners but also for foreign or second language learners in general.
\end{abstract}

\section{Keywords}

visually impaired learners

language learning strategies

second language acquisition

\section{Ethical Lingua}

Vol. 7, No. 1, 2020

ISSN 2355-3448 (Print)

ISSN 2540-9190 (Online)

Corresponding Email

Thi Minh Phuong Tran

minhphuongtrn@hcmussh.ed

u.vn

Article's History

Submitted 27 July 2019

Revised 11 October 2019

Accepted 23 October 2019

\section{DOI}

10.30605/25409190.97

Copyright $\odot 2020$

The Author(s)

This article is licensed under CC BY-NC-SA 4.0 License

\section{(cc) EY-NC-SA}




\section{A Case Study of How Visually Impaired Learners Acquire Language}

The sense of sight is one of the most important senses of human beings. People without the sense of sight may have difficulty interacting with other people and with their environment as compared to those who have it. Many researchers agree that the lack of vision can significantly affect learning in general or language learning in particular (American Foundation for the Blind, 2000; Graham, Berman, \& Bellert, 2015). People acquire language with all five senses to develop four language skills - listening, speaking, reading, and writing - at the same time. If people could not see, how could they acquire language? That question came to our mind when we visited the Audio Books Office in Ho Chi Minh City, where we could find many good books for the blind. Some stories among them were even written by visually impaired people. The term "visually impaired people" is used in this study to refer to those who lost their visual ability at an early point in their life, which caused them difficulty in acquiring language. It was interesting to see how these visually impaired writers described the environment, their feelings and other things with 'a special sight'. The question 'How do visually impaired learners acquire language?' was even more compelling when we learnt that those visually impaired people can also learn English as a foreign language and use it effectively in their jobs.

In the world, there have been a number of studies on teaching English to visually impaired learners. However, most of those studies focused on psychological, cultural and policy features only. For example, Morrow (1999) mainly discussed foreign language learning theories and strategies, social skills and interaction of visually impaired learners with sighted teachers and peers. In this doctoral dissertation, Morrow (1999) analyzed strategies for obtaining access to adaptive technology and to materials in alternate formats that make the study of a foreign language possible for students who are blind. In another study, Money (2010) described the experiences of students who are English language learners with disabilities in public schools from a cross-cultural view. In this research, the author presented the difficulties of visually impaired learners in acquiring English as a second language when immigrating to America from Mexico. Their first language is Spanish. The factors that affect the acquisition of English of the participants in Money's (2010) study are ethical and moral obligations and policies for subgroup assessment.

The traditional progression of second language acquisition from listening and reading to speaking and writing (Ellis, 2001, 2005; Harmer, 2001; Krashen, 2002) is no longer considered the only path to literacy. Obviously, listening cannot be used as a good input for the deaf. Reading, similarly, is not a typical input for the blind. That is the reason why some linguistics researchers tried to find out different methods to teach English for learners with disabilities. For example, in a research report about students with visual impairment in a duallanguage program, Milian \& Pearson (2005) asserted that the process of second language acquisition of visually impaired learners requires strong auditory skills and strong language abilities. Moreover, those special learners must have positive attitudes and be willing to take risk to participate in the dual-language program set up for students with visual impairments.

The number of learners with disabilities is increasing together with the development of population in the world. According to Resnikoff et al. (2004, p. 844), "the number of people with visual impairment worldwide in 2002 was in excess of 161 million, of whom about 37 
million were blind". And English is becoming more and more popular. Therefore, the need to know the appropriate way to learn English for visually impaired learners is significant. As stated by Jedynak (2010, p. 171), "the command of English not only enables VI [visually impaired] learners to communicate in the target language but also leads to new opportunities". Based on questionnaire responses from 18 visually-impaired students who were taking English language courses at Sultan Qaboos University in Malaysia, Ghafri (2015) found that the students faced difficulties in all four skill areas, among which writing skill was the most challenging. From the findings, the author gave some recommendations to reduce the challenges for visually impaired students in learning English.

More recently, Susanto \& Nanda (2018) explored the barriers of visually impaired learners through an ethnographic case study carried out in Bandar Lampung, Indonesia. In this study, the researchers emphasized the role-play pedagogy, musical instruments and the use of screen reader technology in a school for special education. However, it should be noted that the students in Susanto \& Nanda's (2018) study were of Type C - mental retardation. In a review study, Arslantaş (2017) confirmed that visual impaired learners have more advantages in learning foreign languages than sighted learners. When comparing sighted learners with visually impaired learners, with the equal treatment and auditory input, visual impaired learners can have stronger verbal memory due to assistive technology.

In Vietnam, there are only some textbooks compiled for children with visual impairments so that they can follow the national curriculum set up by the Vietnamese Ministry of Education and Training for sighted children. Those textbooks are merely translated into Braille for visually impaired students. In some special schools for those students, for example, Nguyen Dinh Chieu Schools, people use Braille with Vietnamese alphabets to teach Vietnamese. Nguyen Dinh Chieu School in Ho Chi Minh City has a Braille production unit, which includes many talking books, textbooks in Braille, and computer instructions for learners with visual impairments. In recent years, there was also an Audio Books Office in Ho Chi Minh City that provided talking textbooks for visually impaired learners from elementary schools to high schools. The Audio Books Office also provides them with thousands of talking books, including famous novels or modern masterpieces. However, visually impaired learners still encounter many difficulties in finding English materials to learn this language.

Nowadays English is one of the compulsory foreign languages to study in Vietnamese schools and it is the language of global economic integration. The need to teach and learn English is increasing day by day. It is obvious that all students, sighted learners and visually impaired learners, must have the same learning support. But there is no official program dedicated for visually impaired learners. Many studies have been done on how learners acquire English as a second language; however, research on how visually impaired learners acquire English as a foreign language has been quite rare. The present study thus aims to explore the process of acquiring English as a foreign language by visually impaired learners in Vietnam. Specifically, the study aims to address the following two research questions:

(1) How do Vietnamese visually impaired learners acquire English as a foreign language?

(2) What difficulties do they have in learning English, and how do they overcome their difficulties? 


\section{Method}

The primary method used for this study was in-depth interview with two visually impaired Vietnamese adults who have been successful in acquiring English. After making acquaintance with them, the researchers arranged the interviews focusing on the following points:

1. The time when they began studying English, before or after losing the sense of sight, before or after acquiring Vietnamese

2. The way they acquire English, their process of practicing English language skills

3. The difficulties they encounter when studying English in comparison with studying Vietnamese

4. The process of adjustment to acquire English

5. The factors contributing to their English acquisition

6 . The use of English in their current jobs.

The participants of this study were two married adults with visual impairment. They were at the age of 30-35 years old. They can use English in their major jobs or part-time jobs to earn for their living. The interviews were carried out in about 30-40 minutes as a talk in a comfortable environment, where the researchers could record the conversations to keep up with their words and take notes at the same time. The talks were later followed up with phone calls whenever necessary, when there was any information that needed to be confirmed. The first interview with the visually impaired female, named S1, was in March, 2016. The second interview with the visually impaired male, named S2, was in June 2016. They were quite ready to cooperate with us when they understood the aims of the study. After the interviews, both participants' responses were analyzed based on the notes and recordings to address the two main points: (1) The process they acquire English as a foreign language; (2) The factors contributing to second language acquisition success of visually impaired learners.

This present study is significant because the number of students learning English as a foreign language in Vietnam is increasing. The need of understanding how visually impaired learners acquire language and what factors affect their learning success will also increase. This case study can also encourage sighted learners to learn English better. The findings of the study can contribute to the theory of second language acquisition and language teaching. Moreover, the authentic experiences from the two visually impaired participants can also provide strategies of practicing and learning language not only for visually impaired learners but also for second or foreign language learners in general.

\section{Results}

\section{How visually impaired learners acquired English}

In order to know how visually impaired learners started acquiring a language, we began with the question when they lost their vision, when they began their study, before or after losing the sense of sight. In the first interview, S1 told us that she got low vision and lost sight when she was at the age of three. Then she started acquiring Vietnamese language with Braille at the age of eight. When she was twelve, she began learning English at Grade six according to the national curriculum by the Vietnamese Ministry of Education and Training for all children. S2, meanwhile, acquired the Vietnamese language as a sighted learner at his age of six. He followed national education system as any other child in Vietnam until the day he got low vision and lost sense of sight at his eleventh age. After interrupted schooling, he continued 
his study. However, he had to use Braille to gain Vietnamese literacy again and began studying English with Braille at the same time at his age of fourteen. In general, both of the two participants learned English in the dark.

This situation is similar to what Morrow (1999) mentioned in his dissertation that the blind encounter many challenges in accessing adaptive technology and alternative materials in studying foreign languages. However, with the help of their family and their own effort, both participants managed to acquire English for further study and career. So what strategies did they use to acquire English? It is generally agreed that the process of learning English began with listening and reading. Obviously, the two participants could not read as other normal children. When S1 and S2 started learning English, they did not have any appropriate facilities for listening either. What they had at that time was just explanation from teachers and classmates. Braille doesn't have any transcription system to help them transfer what they hear to writing letters for note-taking. Therefore, they had to use their own signs to take notes. In addition, they must use their memory to remember new vocabulary and grammar structures. Both of the two visually impaired learners studied English together with their sighted peers. That means they must follow the principal process of acquiring English in Vietnamese schools at that time which begins with reading and vocabulary learning. At that time there was no software that learners with visual impairments can employ to read.

As S1 and S2 admitted, at first, they found it very difficult to learn English because the English phonetic forms are quite different from the English graphic forms. Meanwhile, the Vietnamese sound forms are similar to the written forms. But later they could adapt some strategies to obtain both Vietnamese and English. S1 shared her experience that she usually paid attention to the meaning of the whole paragraphs, and then meaning of sentences, and meaning of phrases, finally meaning of words when necessary. She only looked up the meaning of some key words that affected her understanding. Similarly to S1, when he first learnt English, S2 was used to learning English vocabulary first like the way he learnt Vietnamese. But later, with the help of a non-profit Australian Program "Jobeto" for Nguyen Dinh Chieu learners, he employed a practical strategy of acquiring English, which provided him with more opportunities of listening and speaking directly with native teachers. In general, the main factor that helped both visually impaired learners overcome their problems in reading and writing was meaningful listening method. Their input sources were only listening from audio devices and listening from native speakers.

S1 acquired both Vietnamese and English as a learner with visual impairment. She used the same strategy of learning language in Vietnamese and in English when she was in lower secondary school, reading texts to learn new vocabulary and practicing writing. She hardly had any chance to practice listening and speaking skills. Therefore, she said she could get nothing in English from her secondary school. When she moved to Ho Chi Minh City, she enrolled in a foundation course to prepare for the university entrance examination and passed the exam. Studying at tertiary level, she recognized the significance of learning English. She continued learning English after a long interrupted time. This time she changed her learning methods, focusing on listening and trying to practice speaking. With the help of audio software devices, she could overcome difficult and long reading texts. However, she had a great deal of difficulty with English writing. It took her much time to rewrite a text or correct her writing mistakes. When she made mistakes in her writing, her teacher pointed out the mistakes in her written feedback. Then she had to rely on an audio software to read out those comments. She then had to try to remember and avoid making the same mistakes. 
S2 acquired English when he already knew how to read Vietnamese texts using Braille. He started from learning words and reading to writing; initially he did not pay much attention to listening and speaking. However, he was faced with a lot of difficulties when he acquired English with the same strategy. He realized this when practicing with native speakers in a charity program. If he did not practice listening and speaking well, he would not be able to use English as a tool. After that, he decided to learn English from listening, to speaking, to reading and finally writing. According to $S 2$, language is speech, not writing. He could not explain or describe his learning strategy. He simply observed and imitated what English native speakers said. That habit then helped him to be self-confident in speaking tests later. Improved listening skills and memorizing ability brought him good experience in communication in his jobs.

The most interesting thing which can be found from the interviews is that those visually impaired learners can use foreign languages successfully. S2 continued his English learning in postgraduate program so that he could get a Master's degree in Psychology. S1 can even get her second degree in English Linguistics and Literature. She told us that she was in the process of learning Chinese to support her work better. She often used both English and Chinese in her jobs.

It is not hard for us to understand the difficulties that those visually impaired learners encountered. S1 acquired Vietnamese as a sighted learner, so he developed the habit of learning word by word when he learnt English. The main strategy he used to acquire English was rote learning. At first, he could not keep pace with his sighted classmates. There was a lack of materials and facilities for learners with disabilities at that time. The most modern tool to support his study was a cassette recorder. He must get knowledge from listening and reading, which was his main input. However, the cassette tapes were sometimes not good in quality. The cassette recorder sometimes did not work. It was more difficult for S2 to acquire language because she moved to the South of Vietnam from the North, and these two regions have very different accents. She found it very hard to recognize the meaning of some southern words. Similarly to S1, S2 relied on listening and reading as her main input. She had to learn all subjects with Braille. Both of the participants said that they often lost the sense of touch with a long reading text. They could not use Braille over a long period of time. In other words, without the help of sound devices, they would not have had enough input to acquire English.

Both S1 and S2 said that they could overcome their difficulties due to different factors. In fact, S1 could gain his B.A. degree in Psychology and continued his study to get an M.A. degree in Psychology. S1 managed to obtain two B.A. degrees, one in Vietnamese Linguistics and Literature and the other in English Linguistics and Literature.

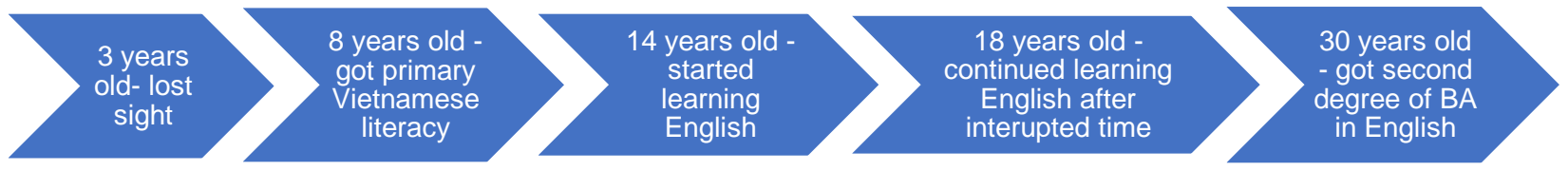

Figure 1. Process of S1's language acquisition

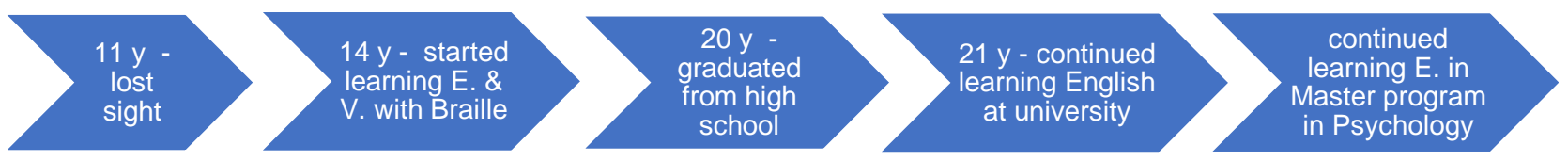

Figure 2. Process of S2's language acquisition 
So what made them successful in learning English? It is generally understood that learners with visually impairments must be provided with appropriate instructions from teachers and sighted peers, necessary help from family and society, and the right support from the government and charity organizations. But how could they take part in the national examination or International English Examinations like IELTS? S2 said that there was an examiner assistant to read the instructions in the test paper for him and he gave the answers on a computer screen. Both participants confirmed that they would not have been able to get any achievement had they not had their family's help in difficult circumstances.

\section{Factors contributing to second language acquisition of visually impaired}

\section{learners}

The very first factor that helps S1 and S2 in learning English is their own personality. They are aware of the difficulties and determine to overcome them. Due to that understanding, they become more adaptive and flexible in all circumstances. For example, they use the sense of touch or hearing instead of the sense of sight. They employ their own transcription to take notes of what they hear to support their memory. They can get used to the study environment with younger classmates or with sighted peers. They must use other senses to replace for the sense of sight so that they can achieve their full potential.

The second factor is the development of computer software that provides reading programs for learners with vision loss. For example, they can use screen readers to read texts that are displayed on the computer screen with a speech synthesizer or Braille display. The visually impaired learners can instruct the speech synthesizer to read or spell a word, read a line or the whole screen of text. S2 told us that he has not had to use Braille any more since there was such a convenient tool.

The visually impaired learners must have received much support from family and society so that they can attain certain results in acquiring language. S2's parents always encouraged him to get along with his classmates and let him develop his own ability. S2 could play the organ in his free time. Interestingly, he could play chess with computer or with sighted players. How could he have done that without his family support? S1's and S2's families sent them to Nguyen Dinh Chieu School so that they could have an appropriate learning environment. Many charity organizations gave funds to support the disabled students there. Among them was a non-profit program of English for the visually impaired learners. Many sponsors gave them facilities to learn better. Their parents also helped them to take care for their child, a fouryear-girl, so that they can be comfortable in their study and in their work.

Both S1 and S2 were put in environments where people must try their best to adapt to different situations in society. S1 told us about the time she had to correct her English writing mistakes. It took her much more effort than a sighted learner to rewrite a task. When teachers corrected her mistakes, there was a reading software program to inform her about the corrections. She practiced writing again and again to complete her task. S1 also found it very difficult to recognize ending sounds, consonant clusters, or blended vowel sounds. Employing a different approach, S2 took advantage of all his time to practice with foreigners who volunteered in his school and everywhere. That experience helped him get higher scores in the IELTS Speaking Test in comparison with other candidates, even with sighted candidates. Both S1 and S2 tried to practice information technology besides learning English so they can now type professionally fast on their computer or smart phone. With the help of reading software, they can reply to an email or electronic message very fast. 
While many university graduates have difficulty in finding a suitable job, S1 and S2 can get their jobs with stable income, perhaps thanks to their ability of using English. S1 currently works as a guide in a restaurant, a special kind of restaurant where people have meals in the dark. Her main duties are to direct guests to the available tables and to take their orders. S1 feels confident to communicate in English with foreign guests coming to the restaurant. She also teaches English for learners with disabilities as her part-time job. Currently, S2 uses English partly in writing reports for a project, or in replying to emails. But he mostly uses English in listening and speaking when necessary. S2 works part-time as a psychologist and an assistant to answer the phone for a limited company in Ho Chi Minh City.

The above factors are very important elements in the process of second language acquisition of the visually impaired learners. But the most significant factor that has a strong impact on their process of acquiring language is their flexibility with their English teachers' teaching methods and their own learning approach. In other words, both the teachers and the two participants must combine and adapt different methods of teaching and independent learning. They not only got knowledge from the traditional Grammar-Translation Method in schools but also learnt from a combination of Communicative Language Teaching approach and AudioLingual method in language centers and outside of class. They said if they just followed one way to practice Reading to Writing, vocabulary to grammar structure as most other sighted students, they could never keep up with the learning curriculum. S1 said she did not try to remember every new word. She just began with the whole paragraph and paid attention to key words only. S2 said he was successful due to the help of "a computer software teacher". That special computer teacher gave him a good teaching method by letting him have a lot of practice with listening. Then he himself developed his speaking skills in reply. The various factors that contribute to the success of the two visually impaired learners (VILs) in second language acquisition are summarized in Figure 3.

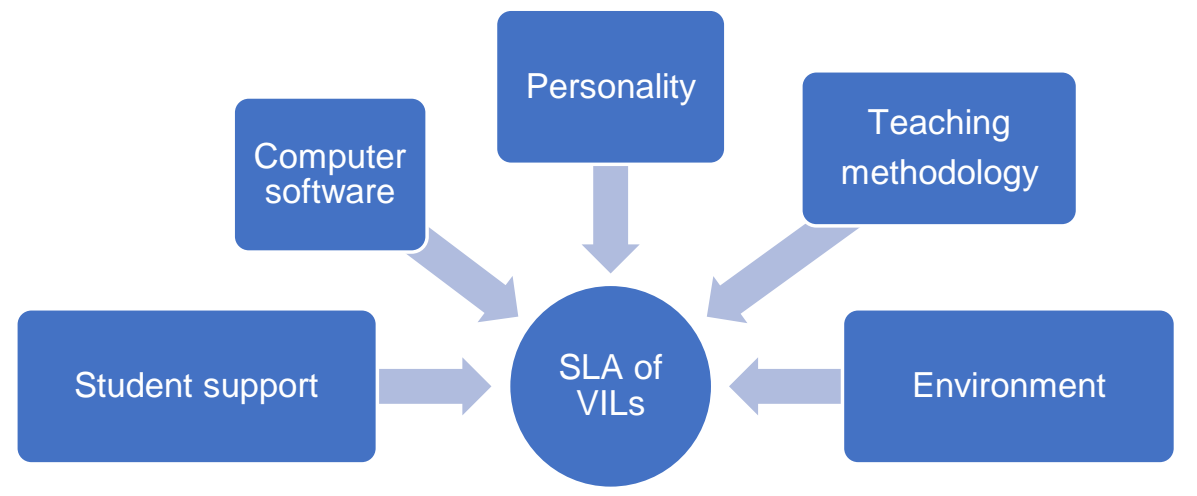

Figure 3. Factors contributing to the success of VILs in second language acquisition

\section{Discussion}

Based on the experiences of the two visually impaired learners, English teachers should provide more instructions for reading tasks in Braille. In particular, having accessible instructional materials is necessary. Learners with visual impairments need to have audiotaped materials designed particularly for them because their main inputs are from listening sources. The steps of teaching vocabulary should be from situations to show the use of words, to their meaning, to their pronunciation, and finally to their spelling. Teachers should use top-down approach for visually impaired learners instead of bottom-up approach, which helps learners with visual impairments get better understanding. In addition, learners 
with similar degrees of vision loss may have different needs. This is because adaptations to vision loss are shaped by individual factors, such as availability and type of family support and degree of intellectual, emotional, physical, and motor functioning. Therefore, a variety of factors needs to be considered in designing an appropriate educational program for blind or visually impaired children.

School systems and parents need to pay proper attention to students with disabilities. In particular, there should be criteria for assessment, where progressive tests are more considered than achievement tests. The ability of each individual learner needs to be assessed and taken into consideration. Each learner with vision loss can have their own strategies of acquiring languages.

Teaching grammar is emphasized for a long time in Vietnam. Learners must learn by heart grammatical rules and employ the same structures in their speaking and writing tasks. However, some grammar rules are not appropriate in conversations. Sometimes that can lead to misunderstanding. Within a communicatively oriented application, learners should understand the content of the whole speaking unit first, which then leads them to their ability to perform communicative tasks automatically. Pronunciation correction should only be made if the error causes incomprehension. Teachers should encourage learners to speak freely and let them self-correct their mistakes later.

The teaching of vocabulary is generally conducted from phonological level to morphological, syntactical and semantic levels. However, vocabulary can be acquired unconsciously or with a certain extent of consciousness if a word is found to be important for comprehension and to be in a meaningful context, as in the case of $X$. as reported earlier. Learners usually study vocabulary by taking an active part in the process and using different language learning strategies to acquire a language. Teachers should pay more attention to the usefulness of vocabulary than its frequency. In general, learners can acquire a language well when they get appropriate input resources.

\section{Conclusion}

This case study describes how two visually impaired learners acquire English as a foreign language. The difficulties which the two participants of this research encounter are what other Vietnamese learners with vision loss may have when they learn English or another language. The challenge of English teachers is how to choose appropriate teaching methods for both sighted and visually impaired learners. Different kinds of learners can also use a variety of learning strategies to acquire languages. For example, one participant in this study used Braille to get input from readings; the other used computer-generated speech to get input from listening.

The contributions of this study are the findings of factors that make those visually impaired learners successful in acquiring English. One developed education system must have a certain policy for teaching learners with disabilities in general or learners with visual impairment in particular. That requires not only teachers to use appropriate teaching methods but also the whole society, family and school to give adequate student support. Due to that precious encouragement, learners with vision loss can try their best to adapt themselves in all situations to develop their best potential. This study has also shown that visually impaired people can contribute their abilities to the work force in society effectively. 
The findings of the present study can contribute to the theory of second language acquisition and language teaching. The study can also provide strategies of practicing and learning language not only for visually impaired learners but also for second or foreign language learners in general.

\section{Acknowledgment}

N/A

\section{References}

American Foundation for the Blind. (2000). Educating students with visual impairments for inclusion in society: A paper on the inclusion of students with visual impairments Retrieved December 27, 2016, from http://www.afb.org/info/programs-andservices/professional-development/teachers/inclusive-education/1235

Arslantaş, T. K. (2017). Foreign language education of visually impaired individuals: A review of pervasive studies. IHEAD: Ihlara Journal of Educational Research, 2(2), 95-104.

Ellis, R. (2001). Second language acquisition. Oxford: Oxford University Press.

Ellis, R. (2005). Instructed second language acquisition - A literature review. Wellington: New Zealand Ministry of Education.

Ghafri, M. (2015). The challenges that visually-impaired students at Sultan Qaboos University face in learning English. In M. S. M. Salleh \& E. Abdullah (Eds.), Proceedings of the 3rd Global Summit on Education 2015 (pp. 506-514). Kuala Lumpur: World Conference Resources.

Graham, L., Berman, J., \& Bellert, A. (2015). Sustainable learning: Inclusive practices for 21st century classrooms. Melbourne: Cambridge University Press.

Harmer, J. (2001). The practice of English language teaching. London: Pearson Education Limited.

Jedynak, M. (2010). Foreign language motivation - Some deliberations on its enhancement in visually impaired learners. In M.-S. A. (Ed.), Anglica Wratis/viensia XLVIII (pp. 171182). Wrocław: Wydawnictwo Uniwersytetu Wrocławskiego.

Krashen, S. (2002). Second language acquisition and second language learning. New York: Pergamon Press Inc.

Milian, M., \& Pearson, V. (2005). Students with visual impairments in a dual-language program: A case study. Journal of Visual Impairment \& Blindness, 99(11), 715-720.

Money, K. W. (2010). The experiences of English language learners with disabilities: A case study analysis. Doctoral dissertation, The University of North Carolina.

Morrow, K. A. (1999). Blind secondary and college students in the foreign language classroom: Experiences, problems and solutions. PhD Dissertation, University of Kansas.

Resnikoff, S. E. A. (2004). Global data on visual impairment in the year 2002. Bulletin of the World Health Organization, 82(11), 844-851.

Susanto, S., \& Nanda, D. S. (2018). Teaching and learning English for visually impaired students: An ethnographic case study. English Review: Journal of English Education, 7(1), 83-92. 